\title{
The Pursuit of Truth in the Company of Friends
}

\section{In Memorium: Charles W. Daniel}

\author{
Gary B. Silberstein ${ }^{1} \cdot$ Michael T. Lewis $^{2}$
}

Published online: 26 November 2016

(C) Springer Science+Business Media New York 2016

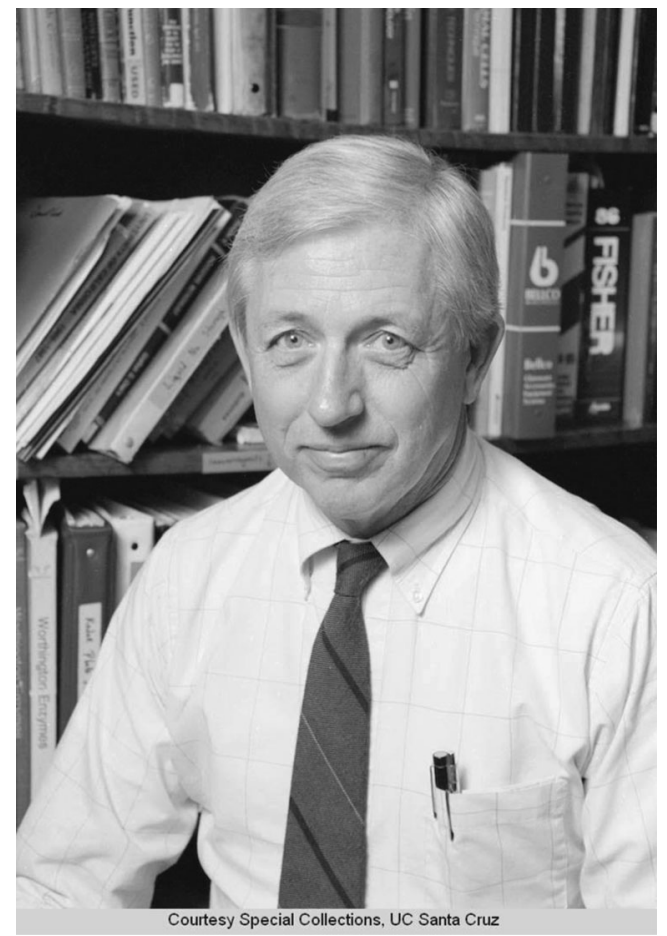

Gary B. Silberstein

gsilbers@ucsc.edu

Michael T. Lewis

mtlewis@bcm.edu

1101 English Drive, Santa Cruz, CA 95065, USA

2 Breast Center, Baylor College of Medicine, One Baylor Plaza, Rm. N-1230.1;MS:BCM600, Houston, TX 77030, USA
This past August mammary gland biology lost a great scientist and friend, Charles W. Daniel. Charles was born in Annapolis, Maryland on June 16th, 1933, where his father attended the Naval Academy. Postwar the family lived in Panama and Shanghai, settling in New Mexico when Charles was a teenager. Charles then attended the University of New Mexico, graduating with a double major in math and literature. He graduated with a Masters in Zoology in 1960, from the University of Hawai' $i$, and returned to the Mainland to begin a Ph.D. program at the University of California, Berkeley in the Zoology Department. At that time the Zoology Department was closely affiliated with the Cancer Research Genetics Laboratory (CRGL) founded by Dr. Kenneth B. DeOme, guided also by endocrinologist Howard Bern [1]. CRGL was the home of the "West Coast Mammary Biology Group" and it was there that Charles began what would become his life's work and calling as a mammary gland biologist.

By 1959, DeOme and his group, working with the mouse, had developed the epithelium-free, 'cleared' fat pad as an in vivo mammary 'culture' system that could be used to investigate the growth, developmental and tumorigenic potential of mammary epithelial cells. As proof-of-principle, fragments of hyperplastic alveolar nodules were transplanted to cleared fat pads and shown to develop into mammary tumors [2]. In 1965, Charles' completed his Ph.D. studies using the DeOme technique to show that outgrowths of mouse mammary cells from primary cell culture, while producing some normal ducts, displayed a variety of culture-induced abnormalities [3].

Coincident with Charles' completed Ph.D. the newest campus of the University of California opened in Santa Cruz. Its mandate, to foster novel approaches to teaching and research. The mammary transplant system was clearly novel and 
Charles, an articulate and energetic, young researcher, was hired as an Assistant Professor that year. From that time until his retirement as a Professor in 1997, Charles used, expanded, and taught the mammary gland research system, publishing seminal works in two major areas of mammary gland biology - cellular aging and ductal growth and morphogenesis. Throughout this long career, what set Charles apart was his ability to "craft" a laboratory and its intellectual environment to ensure its success. This ability, and the loyalty he engendered by it, over time brought to him several long-term colleagues, Phyllis Strickland (almost from inception of the lab), Kathy Van Horn, and Dr. Gary Silberstein, who together formed the core of the lab for many years through to the time of his retirement.

In 1965, Leonard Hayflick demonstrated that serially cultured human diploid cells had a finite mitotic potential, roughly 40-60 cycles, the eponymous 'Hayflick Limit' [4]. Nevertheless, it was widely held that in vivo, cells had unlimited division potential. In a brilliant use of DeOme's protocol, Charles tested this hypothesis by serially transplanting mammary duct fragments and quantifying outgrowth potential. In each successive generation the fragments filled less and less of the fat pad providing unambiguous experimental proof that mitotic senescence was not an artifact of culture [5]. Followon investigations spanning the next 19 years proved that senescence was indeed cell-intrinsic and not a chronologic phenomenon, nor was it due to aging of co-transplanted stromal cells, and furthermore, it could be reversed by neoplastic transformation or elevated intracellular cAMP [6-9]. Subsequent studies of senescent mammary cells, suggest that they are ductal stem cells that could undergo senescence [10].

In the early 1980's, the scope of Charles' research expanded to embrace the critical question of ductal morphogenesis and elongation. In a seminal publication with his graduate student, electron microscopist James Williams, they described in exquisite detail what had been hiding in plain sight, the engine of ductal growth, the mammary terminal end bud (TEB)! [11]. Trenchant topological analysis identified two putative progenitor cell populations, the cap and body cells; the former giving rise to the myoepithelium and basal lamina, the latter, ductal epithelium. With time-lapse cine-microscopy, Williams showed cap cells migrating into the subjacent end bud body, and therefore candidate primary mammary stem cells.

Around this time Gary Silberstein joined the 'Dan Lab' as a cell biologist and developed the 'sustained-release implant' or Elvax method for treating small regions of the mammary gland with hormones, growth factors, and other bio-active agents [12]. Using this technique, a longstanding, fundamental question in mammary gland biology was solved: does estrogen stimulate mammary development through local action or indirectly through systemic intermediaries e.g. growth hormone? Reciprocal implant studies proved estrogen sufficient and necessary for ductal growth and morphogenesis, to wit, estrogen stimulated end bud formation in ovariectomized mice and pure anti-estrogens inhibited it in hormonally intact animals $[13,14]$. From the mid-1980's until his retirement in 1997, and beyond, Charles, his students and postdoctoral fellows, and collaborators went on to publish work describing the functionality and likely natural roles of transforming growth factor- $\beta$ [15] and epidermal growth factor [16], and opened novel lines of research into the roles of homeobox genes [17] and hedgehog signaling [18] in breast development and cancer, among other areas.

Charles' research interests were not limited to the mammary gland. In keeping with the mandate of UCSC, and borne of the shared love and admiration of chickens, he and Sociologist Dr. Page Smith developed a complete course on the biology, evolution, history, and societal impact of the chicken in which students chose an area of "chickendom" to investigate and presented their research in class. These collected reports formed the initial skeleton of a scholarly book on the importance of the chicken to mankind, aptly entitled "The Chicken Book".

As a colleague day-to-day, Charles was creative and insightful able to quickly cut to the heart of a problem and see additional lines of experimentation. He was a great analyst at the microscope, and would frequently gather people around the video monitor to discuss an interesting histology or gene expression pattern. A talented writer and editor, he was a master of brevity, of distilling and sharpening ideas. His 'less is more' management style got the best thinking and work out of his research teams by guiding with a very light hand and then stepping back, trusting the team produce excellent science. When he had a criticism, he would always preface it with a positive observation. And not to forget the Friday 'beer hours' when tongues were loosened, Charles' sharp wit kept us laughing and we discussed some great science!

Charles' interests outside the lab were varied: he was a family man devoted to his wife, Grace and children, Carla, Matt, and Paul, he was an avid fisherman, backpacked the high Sierras solo, and was a serious distance runner, completing several marathons. His interest in videography spawned a mammary gland biology training video that is still useful to newcomers to the field to this day [19]. He was also a lifelong airplane pilot earning an instrument rating.

The sadness that his passing brings us is softened by many happy memories of Charles, of special friends, and the shared struggles and accomplishments that marked a life in science. At one time, Charles had a lab t-shirt made for us on which, under a cartoon of a mouse, was written "The pursuit of truth in the company of friends." That said it all. 


\section{References}

1. Cardiff RD. Contributions to mouse biology to breast cancer research. Comp Med. 2002;52(1):12-31.

2. DeOme KB, Faulkin Jr LJ, Bern HA, Blair PB. Development of mammary tumors from hyperplastic alveolar nodules transplanted into gland-free mammary fat pads of female $\mathrm{C} 3 \mathrm{H}$ mice. Cancer Res. 1959;19:515-20.

3. Daniel CW, DeOme KB. Growth of mouse mammary glands in vivo after monolayer culture. Science. 1965;149:634-6.

4. Hayflick L. The limited in vitro lifetime of human diploid cell strains. Exp Cell Res. 1965;37(3):614-36.

5. Daniel CW, DeOme KB, Young JT, Blair PB, Fauklin Jr LJ. The in vivo life span of normal preneoplastic mouse mammary glands: a serial transplantation study. Proc Natl Acad Sci. 1968;61:52-60.

6. Daniel CW, Aidells BD, Medina D, Faulkin Jr LJ. Unlimited division potential of precancerous mouse mammary cells after spontaneous or carcinogen-induced transformation. Proc FASEB. 1975;34(1):64-7.

7. Daniel CW, Shannon JM, Cunha GR. Transplanted mammary epithelium grows in association with host stroma: ageing of serially transplanted mammary gland is intrinsic to epithelial cells. Mech Ageing Dev. 1983;23:259-64.

8. Daniel CW, Silberstein GB, Strickland P. Reinitiation of growth and normal morphogenesis in serially aged mouse mammary gland. Science. 1984;224:1245-7.

9. Silberstein GB, Trumpbour V, Daniel CW. In vivo, cAMP stimulates growth and morphogenesis of mouse mammary ducts. Proc Natl Acad Sci U S A. 1984;81:4950-4.

10. Smith GH, Strickland P, Daniel CW. Putative epithelial stem cell loss corresponds with mammary growth senescence. Cell Tissue Res. 2002;310(3):313-20.
11. Williams JM, Daniel CW. Mammary ductal elongation: differentiation of myoepithelium and basal lamina during branching morphogenesis. Dev Biol. 1983;97:274-90.

12. Silberstein GB, Daniel CW. Elvax 40P implants: sustained local release of bioactive molecules influencing mammary ductal development. Dev Biol. 1982;93:272-8.

13. Daniel CW, Silberstein GF, Strickland P. Direct action of estradiol on mouse mammary gland analyzed by implantation of sustained release plastic pellets. Cancer Res. 1987;47:6052-7.

14. Silberstein GB, Van Horn K, Shymala G, Daniel CW. Essential role of endogenous estrogen in directly stimulating mammary growth demonstrated by implants containing pure antiestrogens. Endocrinology. 1994;134(1):84-90.

15. Silberstein GB, Daniel CW. Reversible inhibition of mammary gland growth by transforming growth factor-B. Science. 1987;237:291-3.

16. Coleman S, Silberstein GB, Daniel CW. Ductal morphogenesis in the mouse mammary gland: evidence supporting a role for epidermal growth factor. Dev Biol. 1988;127:304-15.

17. Friedmann Y, Daniel CW. Regulated expression of homeobox genes Msx-1 and Msx-2 in mouse mammary gland development suggests a role in hormone action and epithelial-stromal interactions. Dev Biol. 1996;177(1):347-55.

18. Lewis MT, Ross S, Strickland PA, Sugnet CW, Jimenez E, Scott MP, Daniel CW. Defects in mouse mammary gland development caused by conditional haploinsufficiency of patched-1. Development. 1999;126(22):5181-93.

19. Daniel CW, Strickland P. The mouse mammary video: an introduction to the mouse mammary gland and instruction in its surgical manipulation. J Mammary Gland Biol Neoplasia. 2012;17(2):165. 